\title{
Model of indirect Expenses Distribution for Determining Economies of Scale
}

\author{
Oana Panazan ${ }^{1}$, Catalin Gheorghe ${ }^{2}$ and Gavrila Calefariu ${ }^{3}$, \\ ${ }^{1}$ Transilvania University of Brasov, Department of Engineering and Industrial Management, \\ University Street 1 Brasov, Romania, \\ ${ }^{2}$ Transilvania University of Brasov, Department of Engineering and Industrial Management, \\ University Street 1 Brasov, Romania, \\ ${ }^{3}$ Transilvania University of Brasov, Department of Engineering and Industrial Management, \\ University Street 1 Brasov, Romania.
}

\begin{abstract}
Changing economic environment, innovative production technologies and the need to obtain relevant information in decisionmaking, management determines the organizations to seek different approaches to identify economies of scale. Economies of scale are manifested as an effect of cost reduction. The article proposes a comparative analysis of two methods of establishing costs that allow the identification and quantification of economies of scale. The research proposes a distribution of indirect costs depending on the cause-effect relationship between activity and product. The research results show a cost difference in the case of implementing the Activity-based costing (ABC) cost system, thus recognizing the usefulness and compatibility of the method.
\end{abstract}

\section{Introduction}

Economies of scale are a feature of a cost function, which describes the impact on total production costs. The analysis of cost efficiency, factor productivity and economies of scale has identified how companies are affected by the current pandemic situation [1-2]. Profitability driven by economies of scale can lead to lower costs [3]. Increasing volumes of goods and services, made with a certain amount of labour and capital, have led to an increase in living standards through the efficient combination of resources [4]. An efficient configuration of the organization's resources can be monitored with the help of economies of scale. The efficiency of companies with high market authority can be achieved by setting up a price monopoly, but its implementation would trigger a reduction in efficiency [5-6]. The existence of economies of scale is dependent on a directly proportional increase in results, depending on the unitary increase in inputs [7]. Such wording indicates the reduction in unit cost obtained as a result of the increase in production [8-9].

Studies have indicated that market power is advantageous to induce economies of scale and would result in higher productivity [10-11]. The definition of economies of scale does not contain the effects of managerial decisions, which would have a major effect on operational characteristics. Economies of scale refer to changing the total cost for a certain value of production. If production doubles and costs increase by less than $100 \%$, then the

* Gavrilă Calefariu: gcalefariu@,unitbv.ro 
organization shows economies of scale, whether it has increased production by increasing productivity, investing in technology or increasing the size of production capacity [12].

\section{Synthesis of the subject}

Organizations are expanding to strengthen their power and achieve efficiency gains [12]. The lower costs are due to the increase in the size of firms, which achieve a multiplication of capital through economies of scale [13-14]. Although the importance of small organizations cannot be disputed, this sector has seen an increase in the number of firms and production, but also on an operational scale [15-17]. The emergence of economies of scale is chronologically different [18]. The standardized approach to cost function estimation excludes the possibility of inefficient production [19-20]. In terms of cost composition, some elements such as overhead and administrative costs show substantial economies of scale [21]. According to other researchers, economies of scale can be identified in the management of funds, and the achievement of economies of scale is directly proportional to the size of the market [22-23]. Companies investing in aspect technology can lead to inflexible behaviour, which prevents the adjustment of activity to demand and can lead to the emergence of economies of scale [24].

The complexity of activities in companies has led to the updating of traditional methods of cost calculation. A first limitation of these is the inability to identify sectors with costs and productivity independent of other sectors. Another vulnerability is given by the application of methods of redistribution of indirect costs based on the invariable inclusion of resource consumption in cost, which leads to the occurrence of undervaluation, overestimation or subsidization of costs. Another limitation of the traditional methods consists in the development of the support activities, the production of the companies being intensely conditioned by the downstream and upstream activities. With an increase in indirect costs, the traditional model leads to an inadequate relationship between them. Unable to establish a cause and effect relationship between cost and resources, leading to the need for further exploration by other methods [25].

One way to improve the cost system is through the ABC method, as it provides relevant information for decision-making, although it is more complex compared to traditional methods [26-27]. Some companies will be able to benefit from the formative effect of the method more than others [28]. There are several factors that can increase the likelihood of implementation: employee flexibility, management, full understanding of the method, support of companies by professional organizations and continuing education [29]. Operations that use costs for the purpose of generating value and operations that do not generate capital can be identified, thus helping companies to achieve and maintain a competitive position in the market as a whole [30-31]. The application of the method leads to benefits for companies, there is more empirical research on the implementation of the method among organizations [31-33]. Thus, the indirect costs attributed to the activities will be traceable and transparent, through cause-effect relationships, and the vision on operations is obvious [34].

The advantage of estimating the total logarithmic cost function is that it is an approximation of any general function, as it is based on an extension of the second-order Taylor series, as well as due to the influence on economies of scale. A normal distribution of the error term with average zero and constant variance is assumed [12]. Thus, a homothetic production structure is limited to homogeneity, if and only if the cost elasticity in relation to production is constant [36]. The translog cost function is considered, where the constraints, in order to be homothetic and homogeneous, will have the following form [12]: 


$$
T C=f(X, Z, P, T, F)
$$

where $\mathrm{TC}$ is the total cost, $\mathrm{X}$ is a vector of input prices, $\mathrm{Z}$ is a vector of operating characteristics, $\mathrm{P}$ is a measure of the result, $\mathrm{T}$ is a vector of effects over time, and $\mathrm{F}$ is a vector of firm effects.

The use of such a model does not provide a perspective, if the outputs and the size of the network change by a disproportionate amount. As a result, a model of the following form can be used [37]:

$$
T C=f(W, Y, T, F)
$$

Another form of the production function can be considered the solution offered by a Cobb-Douglas production function, if the elasticity of the substitution is very close to the unit value, the case [38].

$$
\ln Y=\ln A_{3}+\alpha_{3} \ln K+\beta_{3} \ln L+\chi_{3} \ln ^{2}\left(\frac{K}{L}\right)
$$

where $\mathrm{Y}$ represents the production (gross domestic product), $\mathrm{K}$ is the fixed capital, $\mathrm{L}$ the employed population, $A_{3}, \alpha_{3}, \beta_{3}$ și $\chi_{3}$ the parameters to be estimated.

Starting from the production function (3), the following form of the function was proposed by constraining $\alpha+\beta=1$, the expression thus becoming a productivity function [39].

$$
\ln Y=\ln A_{\alpha_{i} \beta_{i}}+\sum_{i=1}^{n} \alpha_{i} \cdot \ln X_{i}+\frac{1}{2} \cdot \sum_{i=1}^{n} \sum_{j=1}^{n} \beta_{i j} \cdot \ln X_{i} \cdot \ln X_{j}
$$

The translog production function is a class of flexible functional form [40]. An advantage of the production function is that it does not accept rigid situations, such as the perfect substitution between factors of production or ideal competition in the market of factors of production [41]. Such a function allows the transition from a linear to a nonlinear relationship, and can be used to approximate the second order of a homogeneous linear output.

$$
T C=f(X, P, T, F)
$$

The input price factor (X) takes into account the price of raw materials, labour, transport, operating cost and administrative cost as input variables. These variables were selected because they are representative of society and do not have major corrections. However, the significant correlation becomes an issue in the translog model with the addition of second-order terms.

Relation (5) can be used to estimate the economy in $\operatorname{scale} E_{S}$, or the impact on the cost of increasing production, while keeping input prices constant and allowing all other factors to vary.

$$
E_{S}=\frac{1}{E_{P}}, R T S=\frac{1}{\left(E_{P}-E_{C P S}\right)}, R T D=\frac{1}{E_{P}}
$$

The elasticity of economies of scale $\mathrm{E}_{\mathrm{s}}$ varies, when $E_{P}$ is superunitary, unitary, respectively subunitary. The economies of scale in relation 7 are calculated as 1 minus the derivative of the logarithm of costs in relation to the derivative of the logarithm of production. A positive result indicates an increasing profitability, a negative result indicates scale diseconomies.

$$
E_{E}=1-\frac{\delta \ln C}{\delta \ln P}=0.022
$$


where: $E_{P}$ elasticity of total cost with respect to output; $E_{C P S}$ elasticity of total cost; RTS will refer to the impact on cost of increasing output and network size simultaneously; RTD will refer to the impact on cost of increasing output while holding network size; $E_{E}$ elasticity of scale; $\mathrm{P}$ production sold and $\mathrm{C}$ costs.

\section{Research organization}

\subsection{Determination of economies of scale by statistical method}

In order to determine the economies of scale, the translog cost function was estimated for a company operating in Romania, Brasov County, which assembles locking systems, CAEN code 4618, 159 employees [42]. The company is characterized by a share of staff costs of $11 \%$, raw materials $73 \%$ of the total cost, the difference being transport and administrative costs [42]. The translog cost function will be initially estimated using the Ordinary Least Squares Model (OLS) for a period of one year. The statistical calculations include the total cost of the periods subject to analysis 21596.90 lei, with a standard deviation of 217311.67 lei, considering all 30 products of the company (leu-Romanian currency). The standard deviation is shown because costs vary by product, while production averages 338.07 lei and a standard deviation of 951.83 lei.

Table 1. Statistical data.

\begin{tabular}{|c|c|c|c|}
\hline Period & Variables & Average & $\begin{array}{l}\text { Standard } \\
\text { deviation }\end{array}$ \\
\hline \multirow{8}{*}{ Total } & Total cost & 121596.90 & 217311.67 \\
\hline & Production & 338.07 & 951.83 \\
\hline & \multicolumn{3}{|l|}{ Participation of cost entries } \\
\hline & Raw material & 88199.17 & 157623.44 \\
\hline & Labour force & 13202.55 & 23652.19 \\
\hline & The cost of transport & 1565.71 & 2811.57 \\
\hline & The real cost of operating the installation & 15117.71 & 27019.77 \\
\hline & Administrative cost & 1638.96 & 2984.05 \\
\hline \multirow{8}{*}{ I } & Total cost & 34369.53 & 76878.54 \\
\hline & Production & 127.87 & 405.79 \\
\hline & \multicolumn{3}{|l|}{ Participation of cost entries } \\
\hline & Raw material & 25113.21 & 56173.81 \\
\hline & Labour force & 3013.64 & 6740.98 \\
\hline & The cost of transport & 566.61 & 1267.41 \\
\hline & The real cost of operating the installation & 4480.30 & 10021.64 \\
\hline & Administrative cost & 649.39 & 1452.58 \\
\hline \multirow{8}{*}{ II } & Total cost & 49966.14 & 89649.26 \\
\hline & Production & 155.87 & 454.98 \\
\hline & \multicolumn{3}{|l|}{ Participation of cost entries } \\
\hline & Raw material & 36295.26 & 65120.96 \\
\hline & Labour force & 5525.47 & 9913.80 \\
\hline & The cost of transport & 565.02 & 1013.75 \\
\hline & The real cost of operating the installation & 6476.18 & 11619.56 \\
\hline & Administrative cost & 731.72 & 1312.86 \\
\hline \multirow{3}{*}{ III } & Total cost & 37261.23 & 85285.19 \\
\hline & Production & 54.33 & 102.79 \\
\hline & \multicolumn{3}{|l|}{ Participation of cost entries } \\
\hline
\end{tabular}




\begin{tabular}{|l|c|c|}
\hline Raw material & 26790.70 & 61319.78 \\
\hline Labour force & 4663.44 & 10673.89 \\
\hline The cost of transport & 434.08 & 993.55 \\
\hline The real cost of operating the installation & 4161.23 & 9524.42 \\
\hline Administrative cost & 257.84 & 590.16 \\
\hline
\end{tabular}

The data provided by the organization were statistically processed, in order to identify the type of economies of scale of the company (Table 1). In order to carry out the research, an interim balance sheet was prepared as follows: I (January-April), II (May-August), III (September-December).

Table 2. Results of the translog cost function with OLS.

\begin{tabular}{|l|c|c|c|}
\hline \multirow{2}{*}{ Variable } & \multicolumn{3}{|c|}{ Period } \\
\cline { 2 - 4 } & I & II & III \\
\hline Production sold & $0.11^{*}$ & 0.87 & 0.31 \\
\hline Raw material & 0.12 & 0.9 & 0.3 \\
\hline Labour force & 0.03 & 0.41 & 0.56 \\
\hline The cost of transport & 0.99 & 0.59 & 0.36 \\
\hline Operating cost & 0.12 & 0.88 & 0.14 \\
\hline Administrative cost & 0.6 & 0.13 & 0.01 \\
\hline \multicolumn{3}{|c|}{$* \mathrm{p}<0,05$} \\
\hline
\end{tabular}

In table 2 the data were statistically processed using the Excel program. The correlation between production and the number of employees is shown in Figure 1. Identifying the degree of association of the variables, in this case the result shows a perfect positive association. The linear relationship between the independent variable (number of employees) and the dependent variable (production) was highlighted with a linear regression equation. Bravis-Pearson correlation indices were used to express the causal relationship.

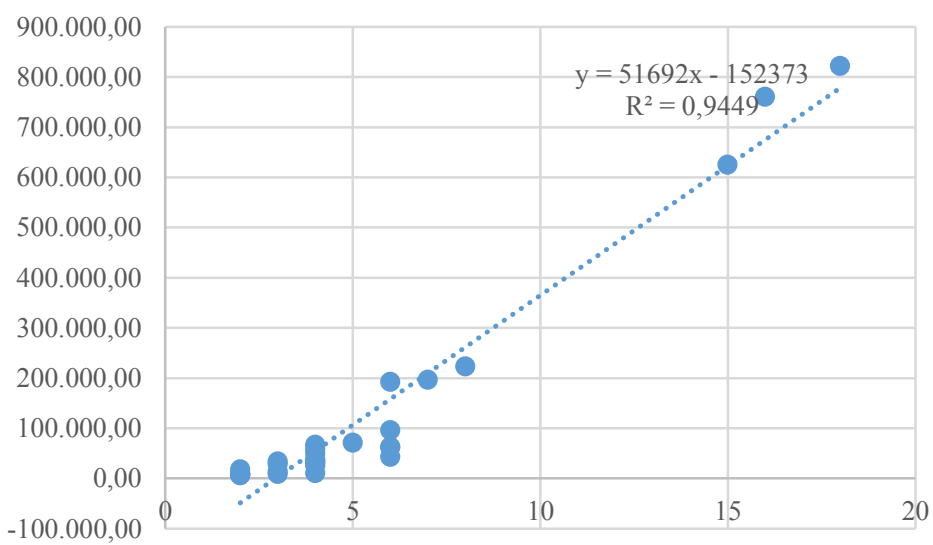

Fig. 1. The correlation between production and employees.

The graph shows a linear relationship between production and the number of employees. The correlation coefficient is 0.9449 . It can be stated that approximately $94 \%$ of the production variation is explained by the participation of employees. In addition, for each increase in the number of employees (with one employee), the value of production increases by 51692 monetary units. For the null hypothesis there are no statistically 
significant differences between the compared means, for the alternative hypothesis there are statistically significant differences between them, because the value of $p$ is greater than 0.05. The calculations show that there are no statistically significant differences between the means compared with two exceptions. In the case of the average labour force in the first period compared to the second period, because $\mathrm{p}$ is 0.03 , less than 0.05 there are statistically significant differences between the labour force in the first period and the labour force in the second period and in the case the average administrative cost in the second period compared to the third period, because $\mathrm{p}$ is 0.01 , less than 0.05 . The results indicate that the allocation of resources according to the models that rejected the null hypothesis in order to represent the production structure is indicated.

\subsection{Determining the cost by the global method}

The analysed company obtained during a management period, carried out during a year, 10142 pieces for which expenses of 20678674 lei were incurred. The standard cost used as a registration price is 2039 lei/piece. (20679538 lei - total standard cost). The statement of expenditure in the accounts is shown in Table 3 [39].

Table 3. Expenditures statistics.

\begin{tabular}{|c|l|c|}
\hline Account & \multicolumn{1}{|c|}{ Expenses } & Sum (lei) \\
\hline 601 & Expenditures on raw materials & 2085993 \\
\hline 602 & Expenses with auxiliary materials & 157010 \\
\hline 603 & Expenses with wear of inventory items & 294592 \\
\hline 605 & Energy and water costs & 121288 \\
\hline 611 & Maintenance and repair costs & 1539505 \\
\hline 612 & Rent expenses & 4961177 \\
\hline 621 & Expenses with collaborators & 139477 \\
\hline 623 & Protocol expenses & 179928 \\
\hline 624 & Expenses for the transport of goods and personnel & 88344 \\
\hline 626 & Postal and telecommunications charges & 946508 \\
\hline 627 & Expenses with banking and similar services & 623145 \\
\hline 635 & Expenses with other taxes and fees & 325319 \\
\hline 641 & Staff remuneration expenses & 6465940 \\
\hline 6451 & $\begin{array}{l}\text { Expenditure on the unit's contribution to social and health } \\
\text { insurance }\end{array}$ & 1481064 \\
\hline 6452 & Unit contribution to the unemployment fund & 323297 \\
\hline 6811 & Operating expenses on depreciation of fixed assets & 946087 \\
\hline & & 20678674 \\
\hline
\end{tabular}

Table 4. Other expenses.

\begin{tabular}{|l|c|c|}
\hline \multicolumn{1}{|c|}{ Expenses } & Type & Sum (lei) \\
\hline Expenditures on raw materials & Direct & 2085993 \\
\hline Expenses with auxiliary materials & Direct & 133459 \\
\hline Expenses with wear of inventory items & Indirect & 15701 \\
\hline Energy and water costs & Administrative & 7850 \\
\hline Maintenance and repair costs & Indirect & 232728 \\
\hline Rent expenses & Administrative & 61864 \\
\hline Expenses with collaborators & Indirect & 82476 \\
\hline Expenses for the transport of goods and personnel & Administrative & 38812 \\
\hline Protocol expenses & Indirect & 1385554 \\
\hline
\end{tabular}




\begin{tabular}{|c|c|c|}
\hline Salary expenses & Administrative & 153951 \\
\hline $\begin{array}{l}\text { Expenditure on the unit's contribution to social and health } \\
\text { insurance }\end{array}$ & Indirect & 3720883 \\
\hline $\begin{array}{l}\text { Expenditure on the unit's contribution to the unemployment } \\
\text { fund }\end{array}$ & Administrative & 1240294 \\
\hline Operating expenses on depreciation of fixed assets & Direct & 139477 \\
\hline TOTAL & 20678674 & \\
\hline
\end{tabular}

Establishing the cost of production is achieved with the additional information forwarded by the production department summarized in Table 4 [42]. The sequence of accounting entry, between the two modes of accounting, revealed in the case of the calculation of actual cost, in which administrative expenses are not included in the cost, expenses of the period remain (not included in cost, in the balance of account 9240). Thus, the expenses that form the production cost are, in this situation, of 20668700 lei. It is observed that the value of the production cost is equal to the sum of the expenses from class 6, of 20678674 lei, from which the administration expenses 4174139 lei were eliminated.

Table 5. Production costs.

\begin{tabular}{|c|c|c|c|c|}
\hline \multirow{2}{*}{ Products } & \multirow{2}{*}{$\begin{array}{c}\text { Quantity } \\
\text { manufactured }\end{array}$} & \multicolumn{2}{|c|}{ Unit cost (lei) } & \multirow{2}{*}{$\begin{array}{c}\text { Machine operating } \\
\text { (hour) }\end{array}$} \\
\hline & & Raw materials & Direct labour & \\
\hline P1 & 237 & 608.77 & 216.78 & 0.01 \\
\hline P2 & 242 & 576.62 & 205.20 & 0.01 \\
\hline P3 & 1151 & 30.32 & 10.39 & 0.02 \\
\hline P4 & 507 & 521.98 & 184.30 & 0.03 \\
\hline P5 & 144 & 2051.41 & 733.64 & 0.02 \\
\hline P6 & 265 & 980.06 & 353.72 & 0.02 \\
\hline P7 & 420 & 288.57 & 102.65 & 0.01 \\
\hline P8 & 639 & 328.47 & 117.53 & 0.01 \\
\hline P9 & 639 & 219.90 & 78.23 & 0.02 \\
\hline P10 & 558 & 133.54 & 46.85 & 0.02 \\
\hline P11 & 230 & 540.82 & 193.05 & 0.02 \\
\hline P12 & 75 & 470.77 & 167.68 & 0.02 \\
\hline P13 & 276 & 575.22 & 206.02 & 0.02 \\
\hline P14 & 368 & 79.25 & 28.39 & 0.011 \\
\hline P15 & 679 & 1370.40 & 494.83 & 0.01 \\
\hline P16 & 1100 & 53.02 & 18.61 & 0.011 \\
\hline P17 & 1808 & 135.75 & 47.68 & 0.01 \\
\hline P18 & 311 & 83.91 & 29.88 & 0.02 \\
\hline P19 & 409 & 96.47 & 34.19 & 0.01 \\
\hline P20 & 340 & 115.36 & 41.36 & 0.02 \\
\hline $\mathrm{P} 21$ & 1082 & 760.10 & 272.53 & 0.02 \\
\hline P22 & 5302 & 493.41 & 175.29 & 0.02 \\
\hline $\mathrm{P} 23$ & 29754 & 107.07 & 38.19 & 0.05 \\
\hline $\mathrm{P} 24$ & 7571 & 106.62 & 38.54 & 0.02 \\
\hline $\mathrm{P} 25$ & 881 & 205.60 & 73.19 & 0.02 \\
\hline $\mathrm{P} 26$ & 282 & 12121.92 & 4346.69 & 0.03 \\
\hline P27 & 570 & 492.55 & 175.48 & 0.02 \\
\hline $\mathrm{P} 28$ & 967 & 413.01 & 148.46 & 0.015 \\
\hline P29 & 253 & 426.08 & 151.84 & 0.03 \\
\hline P30 & 1330 & 33.18 & 11.93 & 0.02 \\
\hline
\end{tabular}


Following the cost calculation by the global method, the cost of the quantity of 10142 pcs. is 20668700 lei. The actual unit cost is 2037.93 lei/piece, if the product is registered in the accounting at a standard (default) cost. The cost differences between the calculated actual cost of 20668700 lei and the standard cost of 20679538 lei must be established. The cost difference -10838 lei is a saving because the actual cost is lower than the standard cost. Analysing the turnover of account 711 , it is observed that it is equal to the credit turnover of account 902, resulting from the sum of the amounts registered on its credit of 20679538 lei. (registration of production at standard cost), and registration of cost differences being 5480 lei, respectively -10838 lei.

The value of the two accounts reflects, in fact, the actual production cost established in both variants, of 20674058 lei and 20668700 lei. The balances of the two accounts are equal and close to each other, reflecting the amount of administrative expenses not included in the cost of production.

Table 6. Indirect costs.

\begin{tabular}{|c|l|l|l|}
\hline No. & \multicolumn{1}{|c|}{ Activity } & Costs (lei) & \multicolumn{1}{c|}{ Cost indicators } \\
\hline 1 & Reception of materials & 141855.43 & Number of material orders \\
\hline 2 & Materials management & 170226.53 & Number of manufacturing orders \\
\hline 3 & Launch assembly & 217511.67 & Number of assembly orders \\
\hline 4 & Equipment department & 293167.91 & Machine operating hours \\
\hline 5 & Quality control & 122941.38 & Number of manufacturing orders \\
\hline Total & 945702.92 & \\
\hline
\end{tabular}

Table 7. Unit and global cost of production calculation.

\begin{tabular}{|c|c|c|c|c|}
\hline Cost elements & Primary cost & Indirect cost & $\begin{array}{c}\text { Production } \\
\text { cost }\end{array}$ & Total cost \\
\hline P1 & 825.55 & 4.71 & 830.26 & 196771.62 \\
\hline P2 & 781.82 & 4.71 & 786,53 & 190340.26 \\
\hline P3 & 40.71 & 9.42 & 50.13 & 57699.63 \\
\hline P4 & 706.28 & 14.13 & 720.41 & 365247.87 \\
\hline P5 & 2785.05 & 9.42 & 2794.47 & 402403.68 \\
\hline P6 & 1333.78 & 9.42 & 1343.20 & 355948 \\
\hline P7 & 391.22 & 4.71 & 395.93 & 166290.6 \\
\hline P8 & 446.00 & 4.71 & 450.71 & 288003.69 \\
\hline P9 & 298.13 & 9.42 & 307.55 & 196524.45 \\
\hline P10 & 180.39 & 9.42 & 189.81 & 105913.98 \\
\hline P11 & 733.87 & 9.42 & 743.29 & 170956.7 \\
\hline P12 & 638.45 & 9.42 & 647.87 & 48590.25 \\
\hline P13 & 781.24 & 9.42 & 790.66 & 218222.16 \\
\hline P14 & 107.64 & 5.18 & 112.82 & 41517.76 \\
\hline P15 & 1865.23 & 4.71 & 1869.94 & 1269689.26 \\
\hline P16 & 71.63 & 5.18 & 76.81 & 84491 \\
\hline P17 & 183.43 & 4.71 & 188.14 & 340157.12 \\
\hline P18 & 113.79 & 9.42 & 123.21 & 38318.31 \\
\hline P19 & 130.66 & 4.71 & 135.37 & 55366.33 \\
\hline P20 & 156.72 & 9.42 & 166.14 & 56487.6 \\
\hline P21 & 1032.63 & 9.42 & 1042.05 & 1127498.1 \\
\hline P22 & 668.70 & 9.42 & 678.12 & 3595392.24 \\
\hline P23 & 145.26 & 23.55 & 168.81 & 5022772.74 \\
\hline P24 & 145.16 & 9.42 & 154.58 & 1170325.18 \\
\hline P25 & 278.79 & 9.42 & 288.21 & 253913.01 \\
\hline & & & & \\
\hline
\end{tabular}




\begin{tabular}{|c|c|c|c|c|} 
P26 & 16468.61 & 14.13 & 16482.74 & 4648132.68 \\
\hline P27 & 668.03 & 9.42 & 677.45 & 386146.5 \\
\hline P28 & 561.47 & 7.06 & 568.53 & 549768.51 \\
\hline P29 & 577.92 & 14.13 & 592.05 & 149788.65 \\
\hline P30 & 45.11 & 9.42 & 54.53 & 72524.9 \\
\hline Total production cost & & 21625202.78 \\
\hline
\end{tabular}

Indirect costs are included in costs as well as direct costs. These items of expenditure may be absorbed by the cost items and the cost allocation is based on an absorption basis (RAI) thus:

$$
\begin{gathered}
R A I=\frac{\text { Total indirect costs }}{\text { Total machine operating hours }(T H F U)}=\frac{945702.92}{2.008}=470.97 \text { (lei/hour) } \\
T H F U=\sum_{i=1}^{30} a_{i} * b_{i}=2.008
\end{gathered}
$$

where $a_{i}$ quantity manufactured, $b_{i}$ machine operating hours, THFU total machine operating hours.

The calculation of the unit and overall cost of production was performed in Table 7 . The cost of production is the sum of direct and indirect costs, and the direct cost consists of the cost of raw materials and direct labour [7].

$$
\begin{aligned}
& C_{p}=C_{d}+C_{i} \\
& C_{d}=C_{R M}+C_{L} \\
& C_{p}=C_{d}+C_{i} \\
& C_{T}=C_{p}^{*} q
\end{aligned}
$$

where $C_{p}$ production cost, $C_{d}$ direct cost, $C_{i}$ indirect manufacturing cost, $C_{R M}$ raw material cost, $\mathrm{C}_{\mathrm{L}}$ labor costs and q quantity manufactured.

\subsection{Determination of cost calculation by indirect cost absorption method and ABC method}

The ABC method of calculating costs is used in different areas of activity due to the ability to organize cost accounting according to the activities of the organization. This method will identify the main differences in cost allocation and identify the reasons why the ABC method contributes to improving costing. The data provided by the organization are in table 7. According to the method, the enterprise is no longer considered a set of entities, but an accumulation of activities.

The products are assembled and then sold in batches of 120 pieces, and the orders of materials were 15 pieces for each type of product [42]. Indirect costs are absorbed in the cost of products according to the number of operating hours of the machines identified in Table 5. The calculation of the unit cost of inductors was performed in Table 8 [43] with respect to:

$$
C_{u i}=\frac{\text { Activity cost }}{\text { Total volume inductors }}
$$

where $\mathrm{C}_{\mathrm{ui}}$ unit cost of inductors. 
Table 8. Unit cost of inductors calculation.

\begin{tabular}{|l|c|l|c|c|}
\hline \multicolumn{1}{|c|}{ Activity } & Cost (lei) & \multicolumn{1}{c|}{ Inductors } & $\begin{array}{c}\text { Inductor } \\
\text { volume }\end{array}$ & $\mathbf{C}_{\mathbf{u i}}$ (lei) \\
\hline $\begin{array}{l}\text { Reception of } \\
\text { materials }\end{array}$ & 141855.43 & Number of material orders & 980 & 144.7504 \\
\hline $\begin{array}{l}\text { Materials } \\
\text { management }\end{array}$ & 170226.53 & Number of manufacturing orders & 990 & 171.9460 \\
\hline Launch assembly & $217,511.67$ & Number of assembly orders & 990 & 219.7088 \\
\hline $\begin{array}{l}\text { Equipment } \\
\text { department }\end{array}$ & 293167.91 & Machine operating hours & 2008 & 146.0000 \\
\hline Quality control & 122941.38 & Number of manufacturing orders & 990 & 124.1832 \\
\hline
\end{tabular}

Calculation of unit and global production cost using relationships (Table 9):

$$
\begin{aligned}
& C_{P}=C_{d}+C_{i} \\
& C_{d}=\left(C_{R M}+C_{L}\right) * q \\
& C_{E C}=C_{\text {uif }} * q * h \\
& C_{l}=C_{\text {uil }} *\left(\frac{q}{n}\right) \\
& C_{R}=C_{\text {uir }} * n_{p} \\
& C_{c}=C_{\text {uic }} *\left(\frac{q}{n}\right) \\
& C_{M M}=C_{\text {uigm }} *\left(\frac{q}{n}\right)
\end{aligned}
$$

where: $\mathrm{Cp}$ production cost, $\mathrm{C}_{\mathrm{d}}$ direct cost, $\mathrm{C}_{\mathrm{i}}$ indirect manufacturing cost, $\mathrm{C}_{\mathrm{RM}}$ raw material cost, $\mathrm{C}_{\mathrm{L}}$ labour costs, q quantity manufactured, $\mathrm{C}_{\mathrm{EC}}$ equipment cost, $\mathrm{C}_{\text {uif }}$ unit cost inductor machine operating hours, h operating hours of equipment/pcs., $\mathrm{C}_{1}$ launch cost, $\mathrm{n}$ number of units sold per lot, $\mathrm{C}_{\mathrm{uil}}$ unit cost inductor launch in manufacturing, $\mathrm{C}_{\mathrm{R}}$ reception cost, $\mathrm{C}_{\mathrm{uir}}$ cost unit inductor material reception, $\mathrm{n}_{\mathrm{p}}$ number of orders for each product, $\mathrm{C}_{\mathrm{C}}$ cost control, $\mathrm{C}_{\text {uic }}$ unit cost inductor control, $\mathrm{C}_{\mathrm{MM}}$ material management cost and $\mathrm{C}_{\text {uigm }}$ unit cost inductor material management.

\section{Results}

The paper presents the existence of economies of scale in an organization, confirming the initial expectations. The extension of the vision related to the relationship between production and production factors can be achieved by estimating the parameters of a translog production, thus making the transition from a linear to a nonlinear system. Accelerating the dynamics of factors of production, in order to increase the level of production, taking into account the context generated by a weak collinearity and an accelerated dynamics of the factor of production, will determine a subunit economy, while a sub-exponential dynamics will determine a economies of scale with a score higher than 1 . The differences identified as a result of the allocation of costs by the two methods identify the best allocation of indirect costs (Figure 2). Comparative situation of unit costs, calculated by the two methods (Table 10).

These are due to indirect cost absorption conventions and can influence price if calculated on the basis of cost plus margin and can influence profit if the price level 
influences sales and last but not least of the benefit if the level of stocks fluctuates from a period to period.

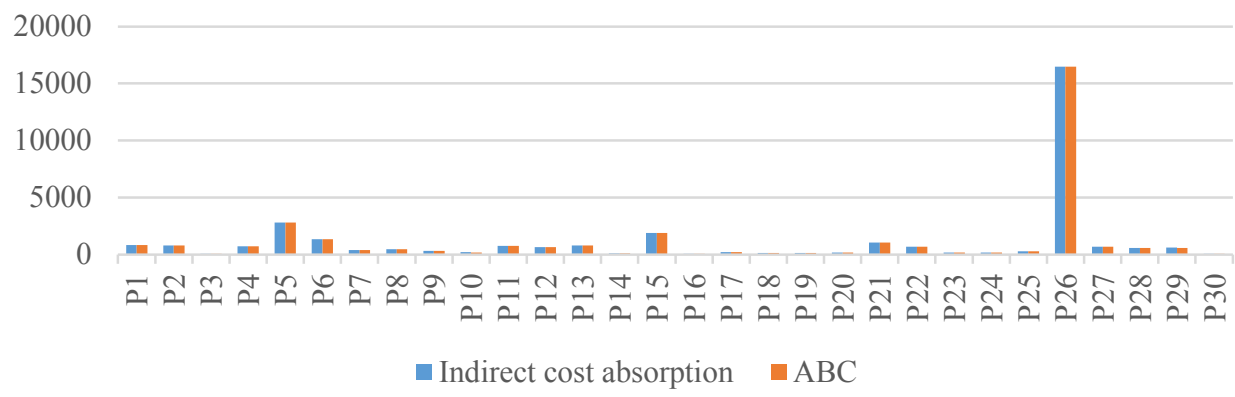

Fig. 2. The difference between the indirect cost absorption method and $A B C$ metho 
Table 9. Costs (lei)

\begin{tabular}{|c|c|c|c|c|c|c|c|c|}
\hline Products & Direct cost & Equipment cost & Launch cost & Reception cost & $\begin{array}{c}\text { Cost } \\
\text { control }\end{array}$ & $\begin{array}{c}\text { Material } \\
\text { management cost }\end{array}$ & Total cost & Unit cost \\
\hline $\mathrm{P} 1$ & 195655.35 & 346.02 & 433.92 & 17.37 & 245.26 & 339.59 & 196697.92 & 829.95 \\
\hline P2 & 189200.44 & 353.32 & 443.08 & 17.37 & 250.44 & 346.76 & 190264.65 & 786.22 \\
\hline P3 & 46857.21 & 3360.92 & 2107.37 & 17.37 & 1191.12 & 1649.25 & 53533.99 & 46.51 \\
\hline $\mathrm{P} 4$ & 358083.96 & 2220.66 & 928.27 & 17.37 & 524.67 & 726.47 & 361774.93 & 713.56 \\
\hline P5 & 401047.20 & 420.48 & 263.65 & 17.37 & 149.02 & 206.34 & 401897.72 & 2790.96 \\
\hline P6 & 353451.70 & 773.80 & 485.19 & 17.37 & 274.24 & 379.71 & 355002.30 & 1339.63 \\
\hline P7 & 164312.40 & 613.20 & 768.98 & 17.37 & 434.64 & 601.81 & 166146.59 & 395.59 \\
\hline P8 & 284994.00 & 932.94 & 1169.95 & 17.37 & 661.28 & 915.61 & 287775.54 & 450.35 \\
\hline P9 & 190505.07 & 1865.88 & 1169.95 & 17.37 & 661.28 & 915.61 & 194219.55 & 303.94 \\
\hline P10 & 100657.62 & 1629.36 & 1021.65 & 17.37 & 577.45 & 799.55 & 103903.45 & 186.21 \\
\hline P11 & 168790.10 & 671.60 & 421.11 & 17.37 & 238.02 & 329.56 & 170138.20 & 739.73 \\
\hline P12 & 47883.75 & 219.00 & 137.32 & 17.37 & 77.61 & 107.47 & 48335.05 & 644.47 \\
\hline P13 & 215622.24 & 805.92 & 505.33 & 17.37 & 285.62 & 395.48 & 217236.48 & 787.09 \\
\hline P14 & 39611.52 & 591.01 & 673.77 & 17.37 & 380.83 & 527.30 & 41274.50 & 112.16 \\
\hline P15 & 1266491.17 & 991.34 & 1243.19 & 17.37 & 702.67 & 972.93 & 1269445.74 & 1869.58 \\
\hline P16 & 78793.00 & 1766.60 & 2014.00 & 17.37 & 1138.35 & 1576.17 & 83729.32 & 76.12 \\
\hline P17 & 331641.44 & 2639.68 & 3310.28 & 17.37 & 1871.03 & 2590.65 & 339479.80 & 187.77 \\
\hline P18 & 35388.69 & 908.12 & 569.41 & 17.37 & 321.84 & 445.63 & 37205.43 & 119.63 \\
\hline P19 & 53439.94 & 597.14 & 748.84 & 17.37 & 423.26 & 586.05 & 55226.55 & 135.03 \\
\hline $\mathrm{P} 20$ & 53284.80 & 992.80 & 622.51 & 17.37 & 351.85 & 487.18 & 55269.33 & 162.56 \\
\hline P21 & 1117305.66 & 3159.44 & 1981.04 & 17.37 & 1119.72 & 1550.38 & 1123583.23 & 1038.43 \\
\hline P22 & 3545447.40 & 15481.84 & 9707.47 & 17.37 & 5486.83 & 7597.15 & 3576140.91 & 674.49 \\
\hline P23 & 4322066.04 & 217204.20 & 54476.80 & 17.37 & 30791.22 & 42634.01 & 4624555.63 & 155.43 \\
\hline P24 & 1099006.36 & 22107.32 & 13861.79 & 17.37 & 7834.93 & 10848.36 & 1142827.77 & 150.95 \\
\hline P25 & 245613.99 & 2572.52 & 1613.03 & 17.37 & 911.71 & 1262.37 & 250728.62 & 284.60 \\
\hline P26 & 4644148.02 & 1235.16 & 516.32 & 17.37 & 291.83 & 404.07 & 4646208.70 & 16475.92 \\
\hline P27 & 380777.10 & 1664.40 & 1043.62 & 17.37 & 589.87 & 816.74 & 384092.36 & 673.85 \\
\hline P28 & 542941.49 & 2117.73 & 1770.49 & 17.37 & 1000.71 & 1385.60 & 547847.79 & 566.54 \\
\hline P29 & 146213.76 & 1108.14 & 463.22 & 17.37 & 261.82 & 362.52 & 148064.31 & 585.23 \\
\hline P30 & 59996.30 & 3883.60 & 2435.11 & 17.37 & 1376.36 & 1905.73 & 67708.74 & 50.91 \\
\hline Total & 20679227.72 & 293234.14 & 106906.66 & 521.10 & 60425.48 & 83666.05 & 21140315.10 & \\
\hline
\end{tabular}


Table 10. Comparative analysis between the obtained results.

\begin{tabular}{|c|c|c|c|}
\hline Products & $\begin{array}{c}\text { Indirect cost absorption } \\
\text { method }\end{array}$ & ABC method & Difference \\
\hline P1 & 830.26 & 829.95 & 0.31 \\
\hline P2 & 786.53 & 786.22 & 0.31 \\
\hline P3 & 50.13 & 46.51 & 3.62 \\
\hline P4 & 720.41 & 713.56 & 6.85 \\
\hline P5 & 2794.47 & 2790.96 & 3.51 \\
\hline P6 & 1343.20 & 1339.63 & 3.57 \\
\hline P7 & 395.93 & 395.59 & 0.34 \\
\hline P8 & 450.71 & 450.35 & 0.36 \\
\hline P9 & 307.55 & 303.94 & 3.61 \\
\hline P10 & 189.81 & 186.21 & 3.60 \\
\hline P11 & 743.29 & 739.73 & 3.56 \\
\hline P12 & 647.87 & 644.47 & 3.40 \\
\hline P13 & 790.66 & 787.09 & 3.57 \\
\hline P14 & 112.82 & 112.16 & 0.66 \\
\hline P15 & 1869.94 & 1869.58 & 0.36 \\
\hline P16 & 76.81 & 76.12 & 0.69 \\
\hline P17 & 188.14 & 187.77 & 0.37 \\
\hline P18 & 123.21 & 119.63 & 3.58 \\
\hline P19 & 135.37 & 135.03 & 0.34 \\
\hline P20 & 166.14 & 162.56 & 3.58 \\
\hline P21 & 1042.05 & 1038.43 & 3.62 \\
\hline P22 & 678.12 & 674.49 & 3.63 \\
\hline P23 & 168.81 & 155.43 & 13.38 \\
\hline P24 & 154.58 & 150.95 & 3.63 \\
\hline P25 & 288.21 & 284.60 & 3.61 \\
\hline P26 & 16482.74 & 16475.92 & 6.82 \\
\hline P27 & 677.45 & 673.85 & 3.60 \\
\hline P28 & 568.53 & 566.54 & 1.99 \\
\hline P29 & 592.05 & 585.23 & 3.62 \\
\hline P30 & 54.53 & 50.91 & \\
\hline & & & \\
\hline & & & \\
\hline
\end{tabular}

\section{Conclusions}

The results of this study show that the presence of economies of scale in the industry market indicates inefficiency in operations, and unit production costs could be reduced by increasing the scale of operations. As long as unit costs can be reduced by increasing production, this approach would be more effective, leading to greater profitability for the organization.

The strategy is only a viable option if additional production can be sold, which may not be the case in a competitive market, but the company has economies of scale, which can be improved by the measures identified by the analysis, ie a cost allocation that to benefit from increased profitability. With the main purpose of illustrating the application of these theoretical relations and to show the importance of potential errors, this paper presents an empirical study conducted on a company operating in Romania. This research can be continued by expanding the analysis by addressing economies of scale by expanding the field of research. 


\section{References}

1. P.M. Romer, JPE 98, 71-102 (1990)

2. M.G. Cruz, Modeling, Measuring and Hedging Operational Risk (Hardcover, Buch, 2002)

3. G.I.P. Ottaviano, G. Peri, J Urb Econ. 58(2), 304-337 (2005)

4. J. Fabina, L.J. Wright Mark, Econ J. 306 (2013)

5. S. Bhuyan, R.A. Lopez, AJAE 79, 1035-1043 (1997)

6. D.M. Hao, X.Q. Wang, JOIE 1, 152-162 (2003)

7. R. Hall, BPEA 18, 285-338 (1986)

8. R. Hall, JPE 96, 921-947 (1988)

9. R. Hall, NBER 3034, 71-112 (1990)

10. D.W. Caves, L.R. Christensen, R. Laurits, M.W. Tretheway, Rand J Econ 15, 471-489 (1984)

11. B.W. Ambrose, M.J. Highfield, P.D. Linneman, REE 33, 323-350 (2005)

12. P. Linneman, Forces changing the real estate industry for-ever (Wharton Real Estate Center, Philadelphia, 1997)

13. J. Dawson, Small Enterp. Dev. 1, 39-46 (1990)

14. T. Timberg, JSBED 1, 26-31 (1990)

15. F. Stewart, Small Enterp. Dev. 1, 4-16 (1990)

16. M. Bers, T.M. Springer, JRER 14, 275-290 (1997)

17. M. Bers, T.M. Springer, REF 15, 37-44 (1998)

18. B.W. Ambrose, S.R. Ehrlich, W.T. Hughes, S.M. Wachter, JREFE 20, 211-224 (2000)

19. D.R. Capozza, P.J. Seguin, REE 26, 131-150 (1998)

20. D.A. Latzko, JFR 22(3), 331-339 (1999)

21. A. Smith, The Wealth of Nations (CreateSpace, Scotts Valley, 2018)

22. J.C. Panzar, R.D. Willig, AER 71, 268-272 (1981)

23. K.A Tiscoski, A.P Beck da Silva Etges, R.J.Vargas Alves, T.Belladona Cardoso, F.Pontes Grando, SD 44, S87 (2019)

24. L. Mauler, F. Duffner, J. Lekera, Ap. En. 286, 116-499 (2021)

25. J. Zhang, H.Tang, D.D. Tannant, C. Lin, D. Xia, X. Liu, Y. Zhang, J. Ma, JCP 293, 126-205 (2021)

26. R.W. Hilton, D.E. Platt, Managerial Accounting: Creating Value in a Dynamic Business Environment (McGraw-Hill Education, New York, 2014)

27. M.D. Shields, S.M. Young, J. Cost Manag. winter, 17-27 (1989)

28. A. Khozein, M. Dankoob, AJBAS 5(10), 613-619 (2011)

29. G.M. Chen, M. Firth, K. Park, Asian Rev. Account. 9(2), 23-37 (2001)

30. W. Chongruksut, A. Brooks, Asian Rev. Account. 13(2), 1321-7348 (2005)

31. J. Innes, F. Mitchell, MAR 6(2), 137-153 (1995)

32. S. Cohen, G. Venieris, E. Kaimenaki, Manag. Audit J. 20(9), 981-1000 (2005)

33. W. Green, Econometric analysis (Prentice Hall, New Jersey, 1998)

34. A. Johnston, J. Ozment, Es. 51, 95-108 (2013)

35. J. Kmenta, IER 8, 180-189 (1967)

36. Z. Grilichs, V. Ringstad Economies of Scale and the Form of the Production Function (North Holland, Amsterdam, 1971)

37. Ch. Allen, St. Hall, Macroeconomic Modelling in a Changing World (Willey, New Jersey, 1997)

38. J. Klacek, M. Vosvrda, S. Schlosser, SCB 4, 261-274 (2007)

39. https://mfinante.gov.ro/ro/web/site/info-pj/ (accessed 2021)

40. C. Scorte, EI 16, 577- 579 (2007) 